Voume :19, Nomor : 2

ISSN Online : 2613-9340

ISSN Offline : 1412-1255

\section{PERTANGGUNGJAWABAN PELAKU TINDAK PIDANA PEMBUNUHAN BERENCANA YANG DILAKUKAN OLEH ANAK (Studi Putusan Pengadilan Negeri Nomor 16/Pid.Sus-Anak/2016/PN.Cbn)}

oleh :

\section{Djesi Ariani ${ }^{1}$}

\begin{abstract}
Children are a mandate from God Almighty which is inherent in their dignity as a whole human being. Every child has dignity and value that is worthy of high regard and every child born must have his/her rights without the child's request. The problems in this thesis are: the responsibility of children as perpetrators in criminal acts of premeditated murder in the Indonesian legal system, legal protection against children as perpetrators of criminal offenses planned in District Court Decision Number 16 / Pid.Sus-Anak / 2016 / PN.Cbn, the legal considerations of the judges against children as perpetrators of premeditated murder in District Court Decision Number $16 /$ Pid.Sus-Anak / 2016 / PN.Cbn.

Legal Protection of Children in Criminal Acts Based on Law Number 11 Year 2012, from the results of the study, it is stated that children who are dealing with the law, including children as victims or children as perpetrators of crime, it is appropriate for children who are in conflict with the law to get legal protection both as the perpetrators or as the victims.
\end{abstract}

Keywords: Criminal Liability, Planned Murder, Children.

\begin{abstract}
Abstrak
Pertanggungjawaban anak sebagai pelaku dalam tindak pidana pembunuhan berencana dalam sistem hukum Indonesia diketahui bahwa Pidana dan jenis pidana penjatuhan Pidana pada Persidangan Anak diatur dalam Pasal 22 sampai dengan 32 Undang-Undang Nomor : 3 Tahun 1997 dan dapat berupa pidana atau tindakan. Apabila diperinci lagi, pidana tersebut bersifat pidana Pokok dan Pidana Tambahan. Pidana Pokok Terdiri dari : Pidana penjara diatur dalam Pasal 26 UU No. 3 tahun 1997 Apabila Anak sebagaimana dimaksud dalam Pasal 1 angka 2 huruf a, Apabila Anak sebagaimana dimaksud dalam Pasal 1 angka 2 huruf a, belum mencapai umur 12 (dua belas) tahun melakukan tindak pidana yang tidak diancam pidana penjara seumur hidup, maka terfadap Anak tersebut dijatuhkan salah satu tindakan sebagaimana dimaksud dalam Pasal 24. Kalau dilihat dari bentuknya maka hukuman penjara dapat berupa seumur hidup untuk sementara. Hukuman penjara untuk sementara mempunyai rentang waktu minimum/algemeene Straftmaxime selama 15 (lima belas) tahun. Perlindungan hukum terhadap terhadap anak sebagai pelaku tindak pidana pembunuhan berencana dalam Putusan Pengadilan Negeri Nomor 16/Pid.SusAnak/2016/PN.Cbn Perlindungan Hukum Pada Anak Pelaku Tindak Pidana Berdasarkan Undang - Undang Nomor 11 Tahun 2012, dari hasil kajian dinyatakan bahwa Anak yang berhadapan dengan hukum, meliputi anak sebagai korban atau anak sebagai pelaku tindak pidana, sudah selayaknya anak yang berhadapan dengan hukum mendapat perlindungan hukum baik pelaku maupun korban.
\end{abstract}

Kata Kunci :Pertanggungjawaban Pidana, Pembunuhan Berencana, Anak.

\footnotetext{
${ }^{1}$ Alumni Magister Hukum Fakultas Hukum UISU
} 
Media Komunikasi dan Informasi Hukum dan Masyarakat

\section{PENDAHULUAN}

Anak merupakan amanah dari Tuhan Yang Maha Esa yang dalam dirinya melekat harkat dan martabat sebagai manusia seutuhnya. Setiap anak mempunyai harkat dan martabat yang patut dijunjung tinggi dan setiap anak yang terlahir harus mendapatkan hak haknya tanpa anak tersebut meminta. Hal ini sesuai dengan ketentuan Konvensi Hak Anak (Convention on the Rights of the Child) yang diratifikasi oleh pemerintah Indonesia melalui Keputusan Presiden Nomor 36 Tahun 1990, kemudian juga dituangkan dalam Undang Undang Nomor 4 Tahun 1979 tentang Kesejahteraan Anak dan Undang-Undang Republik Indonesia Nomor 35 Tahun 2014 Tentang Perubahan Atas Undang-Undang Nomor 23 Tahun 2002 Tentang Perlindungan Anak (selanjutnya disebut dengan UU PA) yang kesemuanya mengemukakan prinsipprinsip umum perlindungan anak, yaitu non diskriminasi, kepentingan terbaik bagi anak, kelangsungan hidup dan tumbuh kembang, dan menghargai partisipasi anak. ${ }^{2}$

Keberadaan anak yang ada di lingkungan kita memang perlu mendapat perhatian, terutama mengenai tingkah lakunya. Dalam perkembangan kearah dewasa, kadang-kadang seorang anak melakukan perbuatan yang lepas kontrol, ia melakukan perbuatan tidak baik. Sehingga merugikan diri sendiri bahkan orang lain.

Anak dengan latar belakang ketidak harmonisan keluarga, tentu akan lebih berpotensi untuk mencari sendiri lingkungan diluar keluarga yang bisa menerima apa

${ }^{2}$ https://anjarnawanyep.wordpress.com/konse p-diversi-dan-restorative-justice/, diakses melalui internet pada tanggal 10 Desember 2018. adanya. Apabila lingkungan tersebut positif tentu akan menyelesaikan masalah si anak dan membawanya kearah yang positif juga. Sebaliknya, jika lingkungan negatif yang didapat, inilah yang justru akan menjerumuskan si anak pada hal-hal yang negatif, termasuk mulai melakukan pelanggaran hukum seperti mencuri, mencopet, bahkan membunuh.

Kedudukan keluarga sangat fundamental dalam pendidikan anak. Apabila pendidikan keluarga gagal, maka anak cenderung melakukan tindakan kenakalan dalam masyarakat dan tidak jarang menjurus ke arah tindakan kejahatan atau criminal. Dalam bukunya yang berjudul Kriminologi, $\mathrm{B}$. Simanjuntak berpendapat bahwa, kondisikondisi rumah tangga yang mungkin dapat menghasilkan "anak nakal", adalah:

1. Adanya anggota lainnya dalam rumah tangga itu sebagai penjahat, pemabuk, emosional.

2. Ketidakadaan salah satu atau kedua orangtuanya karena kematian, perceraian atau pelarian diri.

3. Kurangnya pengawasan orangtua karena sikap masa bodoh, cacat inderanya, atau sakit jasmani atau rohani.

4. Ketidakserasian karena adanya main kuasa sendiri, iri hati, cemburu, terlalu banyak anggota keluarganya dan mungkin ada pihak lain yang campur tangan.

5. Perbedaan rasial, suku, dan agama ataupun perbedaan adat istiadat, rumah piatu, panti-panti asuhan. ${ }^{3}$

Secara sosiologis seseorang yang melakukan tindak pidana kejahatan merupakan hasil perubahan-perubahan sosial dan budaya dalam masyarakat sebagai bentuk deviasi sosial (pelanggaran norma-norma masyarakat). Soerjono Soekanto merumuskan bahwa, deviasi adalah: "penyimpangan

${ }^{3}$ Simanjuntak. Kriminologi. Bandung : Tarsito, 1984, h. 55. 
Media Komunikasi dan Informasi Hukum dan Masyarakat

terhadap kaidah-kaidah dan nilainilai dalam masyarakat. Kaidah-kaidah timbul dalam masyarakat karena diperlukan sebagai pengatur dalam hubungan antara seseorang dengan orang lain, atau antara seseorang dengan masyarakatnya". ${ }^{4}$

Tindak pidana memang tidak hanya dilakukan oleh orang dewasa namun anak juga turut andil dalam melakukan suatu kejahatan yang tidak kalah dengan perbuatan yang dilakukan oleh orang dewasa, memang disayangkan bahwa prilaku kriminalitas dilakukan oleh anak, karena masa anak adalah dimana anak seharusnya bermain dan menuntut ilmu, tapi pada kenyataannya anak zaman sekarang tidak kalah bersaing dengan orang dewasa untuk melakukan tindak pidana, namun Negara membedakan tindak pidana yang dilakukan oleh orang dewasa dan yang dilakukan oleh anak, Negara lebih meringankan tindak pidana yang dilakukan oleh anak karena anak merupakan tunas bangsa dan generasi penerus bangsa sehingga setiap anak pelaku tindak pidana yang masuk sistem peradilan pidana harus diperlakukan secara manusiawi sebagaimana yang termuat dalam UU PA, yaitu nondiskriminasi, kepentingan terbaik bagi anak, hak untuk hidup, kelangsungan hidup dan perkembangannya, serta penghargaan terhadap pendapat anak.

Peradilan Anak merupakan suatu pengkhususan pada lingkungan Peradilan Umum, sebagaimana tercantum dalam ketentuan Pasal 2 Undang-Undang Nomor 3 Tahun 1997 tentang Pengadilan Anak, dengan kualifikasi perkara yang sama jenisnya dengan

${ }^{4}$ Soerjono Soekanto, Sosiologi Suatu Pengantar, Jakarta: PT. Raja Grafindo Persada, 2002, h. 214. yang dilakukan oleh orang dewasa dalam hal melanggar ketentuan dalam Kitab UndangUndang Hukum Pidana (KUHP). Oleh karena hal tersebut, maka secara sistematika hukum (recht sistematisch) isi kewenangan Peradilan Anak tidak akan dan tidak boleh.

1. Melampaui kompetensi absolut (absolute competenties) Badan Peradilan Umum.

2. Memeriksa, mengadili dan memutus perkara-perkara yang telah menjadi kompetensi absolut lingkungan badan peradilan lain, seperti Badan Peradilan Agama.

Salah satu masalah yang sering muncul dimasyarakat adalah tindak pidana pembunuhan, tindak pidana pembunuhan adalah suatu bentuk kejahatan dalam jiwa seseorang dimana perbuatan tersebut sangat bertentangan dengan norma-norma yang ada dalam masyarakat yaitu norma agama dan adat-istiadat, sekaligus bertentangan dengan norma ketentuan hukum pidana dan melanggar hak asasi manusia yaitu hak hidup.

Terhadap anak yang melakukan tindak pidana akan dilakukan tindakan hukum atau proses hukum. Dalam tindakan hukum tersebut, yang masih anak-anak lebih didepankan pada aspek perlindungan hak-hak anak tersebut dalam tiap tingkat pemeriksaannya. Hal ini didasarkan karena dalam diri seorang anak melekat harkat, martabat, dan hak-hak anak sebagaimana layaknya manusia yang harus dijunjung tinggi. Anak sebagai salah satu sumber daya manusia merupakan generasi penerus bangsa, sudah selayaknya mendapatkan perhatian khusus terutama anak yang berperkara dengan hukum. 
Media Komunikasi dan Informasi Hukum dan Masyarakat

Salah satu prinsip yang digunakan dalam perlindungan anak adalah anak itu modal utama kelangsungan hidup manusia, bangsa dan keluarga, untuk itu hak-haknya harus dilindungi. Anak tidak dapat melindungi diri sendiri hak-haknya, banyak pihak yang mempengaruhi kehidupannya. Negara dan masyarakat berkepentingan untuk mengusahakan perlindungan hak-hak anak.

Pembedaan perlakuan dan ancaman yang diatur dalam undang-undang ini dimaksudkan untuk lebih memberikan perlindungan dan pengayoman terhadap anak dalam menyongsong masa depannya yang masih panjang. Selain itu, pembedaan tersebut dimaksudkan untuk memberikan kesempatan kepada anak agar setelah melalui pembinaan akan memperoleh jati dirinya untuk menjadi manusia yang lebih baik, yang berguna bagi diri, keluarga, masyarakat, bangsa dan negara.

Seorang anak yang melakukan tindak pidana juga membutuhkan perlindungan hukum sebagai salah satu cara melindungi tunas bangsa di masa depan, perlindungan hukum terhadap anak menyangkut semua aturan hukum yang berlaku. Perlindungan ini perlu karena anak merupakan bagian masyarakat yang mempunyai keterbatasan secara fisik maupun mental, oleh karena itu anak memerlukan perlindungan dan perawatan khusus. $^{5}$

Perlindungan anak dapat dilakukan secara langsung maupun tidak langsung. Secara langsung, maksudnya kegiatan tersebut langsung ditujukan kepada anak yang menjadi sasaran penanganan langsung.

${ }^{5}$ Harkristuti Harkrisnowo. Menelaah Konsep Sistem Peradilan Pidana Terpadu (dalam Konteks Indonesia). Seminar Keterpaduan Sistem Peradilan Pidana di Danau Toba. Medan . Tanggal 4-5 April 2002, h. 3.
Kegiatan seperti ini, antara lain dapat berupa cara melindungi anak dari berbagai ancaman baik dari luar maupun dari dalam dirinya, mendidik, membina, mendampingi anak dengan berbagai cara, mencegah kelaparan dan mengusahakan kesehatannya dengan berbagai cara, serta dengan cara menyediakan pengembangan diri bagi anak. Sedangkan yang dimaksud dengan perlindungan anak secara tidak langsung adalah kegiatan yang tidak langsung ditujukan kepada anak, melainkan orang lain yang terlibat atau melakukan kegiatan dalam usaha perlindungan terhadap anak tersebut. ${ }^{6}$

Dalam Pasal 20 UU PA, bahwa yang berkewajiban dan bertanggungjawab terhadap penyelenggaraan perlindungan anak adalah negara, pemerintah, masyarakat, keluarga dan orang tua. Jadi yang mengusahakan perlindungan bagi anak adalah setiap anggota masyarakat sesuai dengan kemampuannya dengan berbagai macam usaha dalam situasi dan kondisi tertentu. Perlindungan anak menyangkut berbagai aspek kehidupan agar anak dapat tumbuh dan berkembang dengan wajar sesuai dengan hak asasinya. Dalam masyarakat, ketentuan-ketentuan yang mengatur mengenai masalah perlindungan anak dituangkan pada suatu bentuk aturan yang disebut dengan Hukum Perlindungan Anak.

Pada penelitian ini penulis mengambil kasus sebagaimana tertuang dalam putusan Pengadilan Negeri Cibinong Nomor 16/Pid.Sus-Anak/2016/PN.Cbn bahwa ia anak Saka Tatal Bin Karsila bersama-sama dengan temannya pada Hari Sabtu tanggal 27 Agustus

'Maidin Gultom. Perlindungan Hukum Terhadap Anak, Bandung, PT Refika Aditama, 2008, h..2 
Media Komunikasi dan Informasi Hukum dan Masyarakat

2016 sekitar jam 22.00 WIB bertempat dilahan kosong belakang bangunan showroom mobil seberang SMP Negeri 11 di Jl. Perjuangan Majasem Kp. Situgangga Kelurahan Karyamulya Kecamatan Kesambi Kota Cirebon.

Bermula dari pelaku yang dijemput oleh temannya untuk bertemu dengan kawanan geng motor bernama monraker yang sedang nongkrong sambil minum minuman keras, dimana pelaku dalam hal ini memiliki masalah dengan anak motor XTC sehingga pelaku meminta bantuan dengan anak motor monraker. Akibat perbuatan anak dan temantemannya tersebut menyebabkan Anak Korban Muhammad Rizky Rudiana dan Anak Korban Vina meninggal dunia.

Maraknya terjadi tindak pidana kekerasan yang disertai pembunuhan berencana oleh kelompok masyarakat ataupun kelompok bermotor yang terjadi di banyak wilayah Indonesia yang berakibat dirampasnya sepeda motor dan bahkan tidak sedikit yang kehilangan nyawa akibat dari tindakan penganiayaan dan pembunuhan yang sadis dilakukan para pelaku kelompok bermotor yang marak disebut kelompok begal motor.

Berdasarkan uraian di atas, penulis tertarik untuk meneliti lebih lanjut mengenai tindak pidana pembunuhan berencana yang dilakukan oleh anak dengan judul tesis: Pertanggungjawaban Pelaku Tindak Pidana Pembunuhan Berencana Yang Dilakukan Oleh Anak (Studi Putusan Pengadilan Negeri Nomor 16/Pid.Sus-Anak/2016/PN.Cbn)

\section{A. Latar Belakang}

Undang - Undang Dasar Negara Republik Indonesia Tahun 1945 dalam Pasal 1 ayat (3) UUD 1945 (selanjutnya disingkat sebagai UUD NRI 1945) berbunyi : "Negara Indonesia adalah Negara Hukum". Dimana segala perbuatan yang dilakukan seseorang memiliki akibat yang harus di pertanggungjawaban baik secara perdata maupun pidana.

Pasal 27 ayat (2) UUD NRI 1945 yang berbunyi : "tiap-tiap warga negara berhak atas pekerjaan dan penghidupan yang layak." Dalam hal ini negara ataupun pemerintahan harusnya dapat menghadirkan lapangan kerja yang layak bagi masyarakat sehingga masyarakatpun dapat hidup dengan layak, sehingga tidak ada lagi alasan bagi para pelaku tindak pidana yang selalu beralasan karena tidak memiliki perkerjaan atau uang untuk makan sehari-hari sehingga menghalalkan segala cara.

Anak dengan latar belakang ketidak harmonisan keluarga, tentu akan lebih berpotensi untuk mencari sendiri lingkungan diluar keluarga yang bisa menerima apa adanya. Apabila lingkungan tersebut positif tentu akan menyelesaikan masalah si anak dan membawanya kearah yang positif juga. Sebaliknya, jika lingkungan negatif yang didapat, inilah yang justru akan menjerumuskan si anak pada hal-hal yang negatif, termasuk mulai melakukan pelanggaran hukum seperti mencuri, mencopet, bahkan membunuh.

Kedudukan keluarga sangat fundamental dalam pendidikan anak. Apabila pendidikan keluarga gagal, maka anak cenderung melakukan tindakan kenakalan dalam masyarakat dan tidak jarang menjurus ke arah tindakan kejahatan atau criminal. Dalam bukunya yang berjudul Kriminologi, B. Simanjuntak berpendapat bahwa, kondisi- 
Media Komunikasi dan Informasi Hukum dan Masyarakat

kondisi rumah tangga yang mungkin dapat menghasilkan "anak nakal", adalah:

1. Adanya anggota lainnya dalam rumah tangga itu sebagai penjahat, pemabuk, emosional.

2. Ketidakadaan salah satu atau kedua orangtuanya karena kematian, perceraian atau pelarian diri.

3. Kurangnya pengawasan orangtua karena sikap masa bodoh, cacat inderanya, atau sakit jasmani atau rohani.

4. Ketidakserasian karena adanya main kuasa sendiri, iri hati, cemburu, terlalu banyak anggota keluarganya dan mungkin ada pihak lain yang campur tangan.

5. Perbedaan rasial, suku, dan agama ataupun perbedaan adat istiadat, rumah piatu, panti-panti asuhan. ${ }^{7}$

Perkembangan peradaban dan pertumbuhan pada masyarakat cukup pesat, dimana kejahatan ikut mengiringi dengan caracara yang telah berkembang pula. Kejahatan senantiasa ada dan terus mengikuti perubahan. Pengaruh modernisasi tidak dapat dielakkan, disebabkan oleh ilmu pengetahuan yang telah mengubah cara hidup manusia dan akhirnya hanya dapat untuk berusaha mengurangi jumlah kejahatan serta membina penjahat tersebut secara efektif dan intensif. Maka sulit kalau dikatakan Negara akan melenyapkan kejahatan secara total. Emile Durkheim menyatakan bahwa kejahatan adalah: "suatu gejala normal didalam setiap masyarakat yang bercirikan heterogenitas dan perkembangan sosial dan karena itu tidak mungkin dapat dimusnahkan sampai tuntas". ${ }^{8}$

Berawal dari pemikiran bahwa manusia merupakan serigala bagi manusia lain (Homo homini lupus), selalu mementingkan diri sendiri dan tidak mementingkan orang lain sehingga

${ }^{7}$ Simanjuntak. Kriminologi. Bandung : Tarsito, 1984, h. 55.

${ }^{8}$ Ninik Widiyanti dan Panji Anoraga, Perkembangan Kejahatan dan Masalahnya, Jakarta:Pradya Paramita, 1987, h. 1. bukan hal yang mustahil bagi manusia untuk melakukan kesalahan-kesalahan, baik itu disengaja maupun tidak disengaja, sehingga perbuatan itu merugikan orang lain dan tidak jarang pula merugikan orang lain dan tidak jarang pula melanggar hukum, kesalahan itu dapat berupa suatu tindak pidana (delik).

Salah satu tindak pidana yang dilakukan oleh masyarakat adalah tindak pidana pembunuhan. Pembunuhan adalah setiap pebuatan yang dilakukan dengan sengaja untuk menghilangkan/merampas jiwa orang lain. Selain itu pembunuhan dianggap perbuatan yang sangat terkutuk dan tidak berperikemanusiaan. Dipandang dari sudut agama, pembunuhan merupakan suatu tindakan yang terlarang bahkan tidak boleh dilakukan.

Didalam tindak pidana pembunuhan yang menjadi sasaran si pelaku adalah nyawa seseorang yang tidak dapat diganti dengan apapun. Dan perampasan itu sangat bertentangan dengan Undang-Undang 1945 yang berbunyi: "setiap orang berhak untuk hidup serta berhak mempertahankan hidup dan kehidupannya"

Apabila kita melihat kedalam kitab Undang-Undang Hukum Pidana (yang selanjutnya disingkat KUHP), segera dapat diketahui bahwa pembentuk undang-undang telah bermaksud mengatur ketentuanketentuan pidana tentang kejahatan-kejahatan yang ditujukan terhadap nyawa orang itu dalam Buku ke II Bab ke-XIX KUHP yang terdiri dari tiga belas pasal, yakni dari Pasal 338 sampai dengan Pasal 350.

Salah satu masalah yang sering muncul dimasyarakat adalah tindak pidana pembunuhan, tindak pidana pembunuhan adalah suatu bentuk kejahatan dalam jiwa 
Media Komunikasi dan Informasi Hukum dan Masyarakat

seseorang dimana perbuatan tersebut sangat bertentangan dengan norma-norma yang ada dalam masyarakat yaitu norma agama dan adat-istiadat, sekaligus bertentangan dengan norma ketentuan hukum pidana dan melanggar hak asasi manusia yaitu hak hidup.

Beberapa tahun belakangan ini juga terjadi fenomena-fenomena sosial yang muncul di dalam masyarakat, dimana kejahatankejahatan tindak pidana pembunuhan tidak hanya dilakukan oleh orang dewasa akan tetapi juga dilakukan oleh anak-anak baik secara sendiri-sendiri, maupun secara bersama-sama.

Terhadap anak yang melakukan tindak pidana akan dilakukan tindakan hukum atau proses hukum. Dalam tindakan hukum tersebut, yang masih anak-anak lebih didepankan pada aspek perlindungan hak-hak anak tersebut dalam tiap tingkat pemeriksaannya. Hal ini didasarkan karena dalam diri seorang anak melekat harkat, martabat, dan hak-hak anak sebagaimana layaknya manusia yang harus dijunjung tinggi. Anak sebagai salah satu sumber daya manusia merupakan generasi penerus bangsa, sudah selayaknya mendapatkan perhatian khusus terutama anak yang berperkara dengan hukum.

\section{B. Rumusan Masalah}

1. Bagaimana pertanggungjawaban pidana anak sebagai pelaku dalam tindak pidana pembunuhan berencana dalam sistem hukum Indonesia?

2. Bagaimana perlindungan hukum terhadap terhadap anak sebagai pelaku tindak pidana pembunuhan berencana dalam Putusan Pengadilan
Negeri Nomor 16/Pid.Sus-

Anak/2016/PN.Cbn?

3. Bagaimana pertimbangan hukum hakim terhadap anak sebagai pelaku tindak pidana pembunuhan berencana dalam Putusan Pengadilan Negeri Nomor 16/Pid.Sus-

Anak/2016/PN.Cbn?

\section{Metode Penelitian}

Jenis Metode penelitian ini adalah penelitian hukum normatif (normative legal reserch) yaitu penelitian yang dilakukan dengan cara melakukan pengkajian perundang-undangan yang berlaku dan diterapkan terhadap suatu permasalahan hukum tertentu. ${ }^{9}$

\section{Pembahasan}

1. Pertanggungjawaban adalah bentuk untuk menenutukan apakah seseorang akan dilepas atau dipidana atas tindak pidana yang telah terjadi, dalam hal ini untk mengatakan bahwa seseornag memiliki aspek pertanggung jawaban pidana maka dalam hal itu terdapat beberapa unsur yang harus terpenuhi untuk menyatakan bahwa seseornag tersebut dapat dimintakan pertanggungjawaban. Unsur-unsur tersebut ialah:

a. Adanya suatu tindak pidana

Unsur perbuatan merupakan salah satu unsur yang pokok pertanggungjawaban pidana, karena seseornag tidak dapat dipidana apabila tidak melakukan suatu perbuatan dimana perbuatan yang dilakukan merupan perbuatan yang dilarang oleh undang-undang hal itu sesuai dengan

9 Soejono dan H. Abdurrahman, Metode Penelitian Hukum, Jakarta: Rineka Cipta, 2003, h. 56. 
Media Komunikasi dan Informasi Hukum dan Masyarakat

asas legalitas yang kita anut. Asas legalitas nullum delictum nulla poena sine praevia lege poenali artinya tidak dipidana suatu perbuatan apabila tidak ada UndnagUndang atau aturan yang mengatur mengenai larangan perbuatan tersebut. ${ }^{10}$

\section{b. Unsur kesalahan}

Kesalahan yang dalam bahasa asing disebut dengan schuld adalah keadaan psikologi seseorang yang berhubungan dengan perbuatan yang ia lakukan yang sedemikian rupa sehingga berdasarkan keadaan tersebut perbuatan tersebut pelaku dapat dicela atas perbuatannya. ${ }^{11}$ Pengertian kesalahan di sini digunakan dalam arti luas. Dalam KUHP kesalahan digunakan dalam arti sempit, yaitu dalam arti kealpaan sebagaimana dapat dilihat dalam rumusan bahasa Belanda yang berada dalam pasal 359 dan 360 .

Dari suatu perbuatan yang telah terjadi maka orang lain akan menilai menurut hukum yang berlaku apakah terhadap perbuatan tersebut terdapat kesalah baik disengaja maupun karena suatu kesalahan kealpaan.

1) Kesengajaan

Dalam tindak pidana kebanyakan di Indonesia memiliki unsur kesengajaan atau opzettelijik bukan unsur culpa. Hal ini berkaitan bahwa orang yang lebih pantas mendapatkan hukuman adalah orang yang melakukan hal tersebut atau melakukan tindak pidana dengan unsur kesengajan. Mengenai unsur kesalahan yang disengaja ini tidak perlu dibuktikan bahwa pelaku mengetahui bahwa perbuatananya

10 Moeljalento, 2008, Asas-Asas Hukum Pidana, Edisi revisi, Jakarta, Renika Cipta, h. 25

11 Frans Maramis, 2012, Hukum Pldana Umum dan Tertulis di Indonesia, Jakarta, Raja Grafindo Persada, h. 114 diancam oleh undang-undang, sehingga tidak perlu dibuktikan bahwa perbuatan yang dilakukan oleh pelaku merupakan perbuatan yang bersifat "jahat". Sudah cukup dengan membuktikan bahwa pelaku menghendaki perbuatannya tersebut dan mengetahui konsekuensi atas perbuataannya.

Kesengajan telah berkembang dalam yurisprudensi dan doktrin sehingga umumnya telah diterima beberapa bentuk kesengajaan, yaitu : ${ }^{12}$

1. Sengaja sebagai maksud

Sengaja sebagai maksud dalam kejahatan bentuk ini pelaku benar-benar menghendaki (willens) dan mengetahui (wetens) atas perbuatan dan akibat dari perbuatan yang pelaku perbuatan. Diberi contoh A merasa dipermalukan oleh $\mathrm{B}$, oleh karena itu $A$ memiliki dendam khusus terhadap $B$, sehingga $A$ memiliki rencana untuk mencelakai $B$, suatu hati $A$ membawa sebilah pisau dan menikam $B$, menyebabkan $B$ tewas, maka perbuatan $A$ tersebut dapat dikatakan adalah perbuatan yang benar-benar ia kehendaki. Matinya $B$ akibat tikaman pisau A juga dikehndaki olehnya. $^{13}$

2. Sengaja sebagi suatu keharusan

Kesangajan semacam ini terjadi apabila sipelaku dengan perbuatannya tidak bertujuan untuk mencapi akibat dari perbuatanya, tetapi ia melakukan perbuatan itu sebagai keharusan untuk mencapai tujuan yang lain. Artinya kesangajan dalam bentuk ini, pelaku menyadari perbuatan yang ia kehendaki namun pelaku tidak
12 Ibid, h. 121
13 Ibid, h. 122 
Media Komunikasi dan Informasi Hukum dan Masyarakat

menghendaki akibat dari perbuatan yang telah ia perbuat. ${ }^{14}$

3. Sengaja Sebagi kemungkinan

Dalam sengaja sebagai kemungkinan, pelaku sebenarnaya tidak menghendaki akibat perbuatanya itu, tetapi pelaku sebelumnya telah mengethaui bahwa akibat itu kemungkinan juga dapat terjadi, namun pelaku tetap melakukan perbuatannya dengan mengambil resiko tersebut.

\section{2) Kealpaan (culpa)}

Dalam pasal-pasal KUHPidana sendiri tidak memberikan definisi mengenai apa yang diamksud dengan kealpaan. Sehingga untuk mengerti apa yang dimaksud dengan kealpaan maka memerlukan pendapat para ahli hukum. Kelalaian merupakan salah satu bentuk kesalahan yang timbul karena pelakunya tidak memenuhi standar yang telah ditentukan, kelalian itu terjadi karena perilaku dari orang itu sendiri.

Kelalain yang ia sadari atau alpa adalah kelalain yang ia sadari, dimana pelaku menyadari dengan adanay resiko namun tetap melakukan dengan mengambil resiko dan berharap akibat buruk atau resiko buruk tidak akan terjadi. Sedangkan yang dimaksud dengan kelalaiam yang tidak disadari atau lalaiadalah seseornag tidak menyadari adanya resiko atau kejadian yang buruk akibat dari perbuatan ia lakukan pelaku berbuat demikian dikarenan anatar lain karena kurang berpikir atau juga bisa terjadi karena pelaku lengah denagn adanya resiko yang buruk.

\section{b. Adanya pembuat yang dapat bertanggung} jawab
Kemampuan bertanggungjawab selalu berhubungan dengan psycis pembuat. Kemapuan bertanggungjawab ini selalu dihubungkan dengan pertanggungjawaban pidana, hal ini yang menjadikan kemampuan bertanggungjawaban menjdai salah satu unsur pertanggungjawaban pidana. Kemampuan bertanggung jawab merupakan dasar untuk menentukan pemidanaan kepada pembuat. Kemampuan bertanggung jawab ini harus dibuktikan ada tidaknya oleh hakim, karena apabila seseorang terbukti tidak memiliki kemampuan bertanggung jawab hal ini menjadi dasar tidak dipertanggungjawabkannya pembuat, artinya pembuat perbuatan tidka dapat dipidana atas suatu kejadian tindak pidana.

Kemampuan bertanggung jawab juga berhubungan dengan umur tertentu bagi pelaku tindak pidana. Artinya hanya pelaku yang memenuhi batas umur tertentu yang memilki kemampuan bertanggung jawab serta memilki kewajiban pertanggung jawaban atas perbuatan yang telah dilakukan, hal ini dikarenakan karena pada umur tertentu secara psycologi dapat mempengaruhi seseorang untuk melakukan suatu perbuatan. Pada dasar nya anak pada umur tertentu belum dapat menyadari dengan baik apa yang telah dilakukan, artinya anak pad aumur tertentu juga tidak dapat memisahkan mana yang baik dan mana yang salah tentu juga hal ini mempengaruhi anak tidak dapat menginsafkan perbuatannya. Apabila anak pada tertentu melakukan tindak pidana dan oleh karena perbuatannya dilakukan proses pidana makan

14 Ibid, h.122 
Media Komunikasi dan Informasi Hukum dan Masyarakat

secara psycologi anak tersebut akan terganggu dimasa dewasanya. ${ }^{15}$

Dalam proses pemidanaan nya hakim wajib memcari dan membuktikan apakah pelaku memiliki unsur kemampuan bertanggung jawab, sebab apabila pelaku tidak memiliki kemampuan bertanggung jawab baik karena usia yang belum cukup umur, atau dikarenakan keadaan psycologi seseorang terganggu maka orang tersebut tidak dapat diminta pertanggung jawabanya.

\section{c. Tidak ada alasan pemaaf}

Dalam keadaan tertentu seseorang pelaku tindak pidana, tidak dapat melakukan tindakan lain selain melakukan perbuatan tindak pidana, meskipun hal itu tidak di inginkan. Sehingga dengan perbuatan tersebut pelaku nya harus menghadi jalur hukum. Hal itu tidak dihindari oleh pelaku meskipun hal itu tidak diinginkan oleh dirinya sendiri. Hal itu dilakukan oleh seseorang karena factor-faktor dari luar dirinya. ${ }^{16}$

Faktor-faktor dari luar dirinya atau batinnya itulah yang menyebabkan pembuat tindak oidana tidak dapat berbuat lain yang mengakibatkan kesalaahannya menjadi terhapus. Artinya, berkaitan dengan hal ini pembuat tindak pidana terdapat alasan penghapusan pidana, sehingga pertanggujawaban berkaitan dengan hal ini ditunggukan smapai dapat dipastikan ada tidaknya unsur alasan pemaaf dalam diri pelaku pembuat tindak pidana tersebut. Dalam hal ini sekalipun pelaku pembuat tindak pidana

15 Agus Rusianto, 2016, Tindak Pidana dan Pertanggung Jawaban Pidana, Prenada media Group, Jakarta, h. 80

16 Chairul Huda, 2006, Dari tiada Pidana tanpa Kesalahan Menuju Tiada Pertanggungjawaban Pidana Tanpa Kesalahan, Jakarta, Kencana, h. 116 dapat dicela namun celaan tersebut tidak dapat dilanjutkan kepadanaya karena pembuat tindak pidana tidak dapat berbuat lain selain melakukan tindak pidana tersebut. ${ }^{17}$

Dalam pemeriksaan perkara hakim harus memperhatikan terkait pembuktian, karena hasil dari pembuktian tersebut nantinya akan digunakan sebagai bahan pertimbangan untuk memutus perkara. Pembuktian adalah tahap yang sangat penting dalam pemeriksaan di persidangan. Tujuan pembuktian adalah untuk memperoleh kepastian bahwa suatu peristiwa / fakta yang diajukan itu benar-benar terjadi, guna mendapatkan putusan hakim yang benar dan adil. Hakim tidak akan bisa menjatuhkan suatu putusan sebelum nyata baginya bahwa peristiwa / fakta tersebut benarbenar terjadi, yakni dibuktikan kebenaranya, sehingga nampak adanya hubungan hukum antara para pihak. ${ }^{18}$

Putusan hakim sangat berkaitan dengan bagaimana hakim dalam mengemukakan pendapat atau pertimbangannya berdasarkan fakta-fakta serta alat bukti dipersidangan serta keyakinan hakim atas suatu perkara.Oleh sebab itu hakim memiliki peran sentral dalam menjatuhkan putusan pengadilan. Didalam putusan pengadilan harus terdapat pertimbangan-pertimbangan mengenai hal-hal yang memberatkan dan meringankan putusan, pertimbagan tersebut dijadikan alasan oleh hakim dalam menjatuhkan putusannya baik itu berupa putusan pemidanaan yang lain sebagainya. $^{19}$

\footnotetext{
17 Ibid.

$18 \mathrm{lbid}, \mathrm{h} .141$.
}

19 Nurhafifah dan Rahmiati. 2015. Pertimbangan Hakim Dalam Penjatuhan Pidana Terkait Hal Yang Memberatkan Dan Meringankan Putusan. Banda Aceh. Jurnal IImu Hukum. No. 66. Fakultas Hukum. UNSYIAH. h. 344. 
Media Komunikasi dan Informasi Hukum dan Masyarakat

Pertimbangan mengenai hal-hal yang memberatkan dan meringankan terdakwa ini diatur dalam Pasal 197 huruf $d$ dan 197 huruf $f$ KUHAP Dalam Pasal 197 huruf $d$ berbunyi "Pertimbangan yang disusun secara ringkas mengenai fakta dan keadaan beserta alat pembuktian yang diperoleh dari pemeriksaan disidang yang menjadi dasar penentuan kesalahan terdakwa". Sedangkan Pasal 197 huruf $f$ berbunyi "Pasal peraturan perundangundangan yang menjadi dasar pemidanaan atau tindakan dan peraturan perundangundangan yang menjadi dasar hukum dari putusan, disertai keadaan yang memberatkan dan meringankan terdakwa". ${ }^{20}$

Ada beberapa faktor yang mempengaruhi hakim dalam membuat putusannya, dibagi menjadi faktor subjektif dan faktor objektif. Faktor subjektif meliputi:

a. Sikap prilaku apriori, yakni adanya sikap hakim yang sejak semula sudah menganggap bahwa terdakwa yang diperiksa dan diadili adalah orang yang memang bersalah dan harus dipidana.

b. Sikap perilaku emosional, yakni putusan pengadilan akan dipengaruhi oleh perangaihakim. Hakim yang mempunyai perangai mudah tersinggung akan berbeda dengan perangai hakim yang tidak mudah tersinggung.

c. Sikap arrogance power, yakni sikap lain yang mempengaruhi suatu putusan adalah "kecongkakkan kekuasaan", disini hakim merasa dirinya berkuasa dan pintar, melebihi orang lain (jaksa, pembela, ataupun terdakwa).

d. Moral, yakni moral seorang hakim karena bagaimanapun juga pribadi seorang hakim diliputi oleh tingkah laku yang didasari oleh

20 Ibid, h. 345. moral pribadi hakim tersebut dalam memeriksa serta memutuskan suatu perkara. ${ }^{21}$

Faktor objektif meliputi :

a. Latar belakang budaya, yakni kebudayaan, agama, pendidikan seseorang tentu ikut mempengaruhi putusan hakim. Meskipun latar belakang hidup budaya tidak bersifat determinis, tetapi faktor ini setidaknya ikut mempengaruhi hakim dalam mengambil suatu keputusan.

b. Profesionalisme, yakni kecerdasan serta profesionalisme seorang hakim ikut mempengaruhi putusannya. Perbedaan suatu putusan sering dipengaruhi oleh profesionalisme hakim tersebut. ${ }^{22}$

Hakim dalam mengadili pelaku tindak pidana harus melalui proses penyajian kebenaran dan keadilan dalam suatu putusan pengadilan sebagai rangkaian proses penegakan hukum. Dalam menjatuhkan putusan hakim harus memiliki dasar pertimbangan yang didasarkan pada keyakinan serta didukung oleh adanya alat-alat bukti yang sah sehingga putusan yang dijatuhkan hakim benar-benar memenuhi rasa keadilan masyarakat. Hakim dalam mnjatuhkan putusan harus mempertimbangkan banyak hal, baik itu yang berkaitan dengan perkara yang sedang diperiksa, tingkat perbuatan dan kesalahan

21 Yahya Harahap, sebagaimana dikutip $M$. Syamsudin. 2012. Konstruksi Baru Budaya Hukum Hakim Berbasis Hukum Progresif. Jakarta. Kencana. h. 93.

22 LH Permana. 2016. Analisis Pertimbangan Hukum Hakim Dalam Penjatuhan Pidana Di Bawah Minimum Terhadap Pelaku Tindak Pidana Kesusilaan. Lampung. Jurnal. Fakultas Hukum. Universitas Lampung. h. 9. 
Media Komunikasi dan Informasi Hukum dan Masyarakat

yang dilakukan pelaku, kepentingan pihak korban, keluarganya dan rasa keadilan. ${ }^{23}$

2. Perlindungan Hukum Terhadap Anak Sebagai Pelaku Tindak Pidana Pembunuhan Berencana Dalam Putusan Pengadilan Negeri Nomor 16/Pid.Sus-Anak/2016/PN.Cbn.

Perlindungan anak dalam UndangUndang Nomor 35 Tahun 2014 tentang Perlindungan Anak diartikan sebagai segala kegiatan untuk menjamin dan melindungi anak dan hak-ahak anak agar dapat hidup, tumbuh, berkembang, dan berpartisipasi secara optimal sesuai dengan harkat dan martabat kemanusiaan serta mendapat perlindungan dari kekerasan dan diskriminasi. Mendapatkan perlindungan merupakan hak dari setiap anak, dan diwujudkannya perlindungan bagi anak berarti terwujudnya keadilan dalam suatu masyarakat.

Perlindungan anak dalam hukum pidana, selain diatur dalam Pasal 45, Pasal 46, dan Pasal 47 KUHP ( telah dicabut dengan diundangkannya Undang-Undang Nomor 3 Tahun 1997 tentang Peradilan Anak). Kemudian terdapat juga beberapa Pasal yang secara langsung atau tidak lang-sung berkaitan dengan perlindungan anak yaitu antara lain Pasal 278, Pasal 283, Pasal 287, Pasal 290, Pasal 301, Pasal 305, Pasal 308, Pasal 341, dan Pasal 365 KUHP. Selanjutnya, dalam Undang-Undang Nomor 35 tahun 2014 tentang Perlindungan Anak yang pada prinsipnya mengatur mengenai perlindungan hak hak anak. Dalam Undang-Undang Nomor 4 tahun 1979 tentang Kesejahteraan Anak.

23 R Afandi. Analisis Dasar Pertimbangan Hukum Hakim Dalam Menjatuhkan Pidana Terhadap Pelaku Pencabulan Terhadap Anak. Dalam http://download.portalgaruda.org. access 18 Mei 2019.
Selanjutnya Pasal 3 Undang-Undang Nomor 23 Tahun 2002 tentang Perlindungan Anak mengatur bahwa perlindungan anak bertujuan untuk menjamin terpenuhinya hakhak anak agar dapat hidup, tumbuh, berkembang, dan berpartisipasi secara optimal sesuai dengan harkat dan martabat kemanusiaan, serta mendapat perlindungan dari kekerasan dan diskriminasi, demi terwujudnya anak Indonesia yang berkualitas, berakhlak mulia, dan sejahtera.

Undang-Undang Nomor 35 Tahun 2014 tentang Perubahan atas Undang-Undang Nomor 23 Tahun 2002 tentang Perlindungan Anak juga mengatur mengenai perlindungan khusus terhadap anak yang berhadapan dengan hukum.

Mengenai perlindungan khusus terhadap anak korban tindak kekerasan diatur dalam Pasal 69 Undang-Undang Nomor 35 Tahun 2014 tentang Perlindungan Anak yang menyatakan bahwa perlindungan khusus bagi anak korban kekerasan sebagaimana dimaksud dalam Pasal 59 meliputi kekerasan fisik, psikis, dan seksual dilakukan melalui upaya:

1) Penyebarluasan dan sosialisasi ketentuan peraturan perundang-undangan yang melindungi anak korban tindak kekerasan; dan

2) Pemantauan, pelaporan, dan pemberian sanksi.

Pemerintah sebagaimana amanat UndangUndang Nomor 23 Tahun 2002 tentang Perlindungan Anak telah membentuk Komisi Perlindungan Anak Indonesia (KPAl) guna memberikan perlindungan terhadap anak Indonesia.

Undang-Undang Perlindungan Anak mengamanatkan pembentukan lembaga yang 
Media Komunikasi dan Informasi Hukum dan Masyarakat

bersifat independen dalam rangka meningkatkan efektifitas penyelenggaraan perlindungan anak maka terbentuklah KPAI Melalui Keppres Nomor 77 Tahun 2003 tentang Komisi Perlidungan Anak Indonesia. KPAI dalam menjalankan kegiatannya memiliki tugas-tugas yaitu:

a. Melakukan sosialisasi seluruh ketentuan peraturan perundang-undangan yang berkaitan dengan perlindungan anak mengumpulkan data dan informasi, menerima pengaduan masyarakat, melakukan penelaahan, pemantauan, evaluasi dan pengawasan terhadap penyelengga-raan perlindungan anak.

b. Memberikan laporan, saran, masukan dan pertimbangan kepada presiden dalam rangka perlindungan anak.

Undang-Undang Nomor 11 Tahun 2012 Tentang Sistem Peradilan Pidana Anak (SPPA) yang diundangkan pada tanggal 30 Juli 2012 (TLNRI 2012-153) merupakan pengganti Undang-Undang Nomor 3 Tahun 1997 tentang Pengadilan Anak yang efektif mulai berlaku setelah 2 (dua) tahun terhitung sejak tanggal diundangkan. Apabila ditelusuri, alasan utama pengganti Undang-Undang tersebut dikarenakan Undang-Undang Nomor 3 Tahun 1997 sudah tidak sesuai lagi dengan perkembangan dan kebutuhan hukum masyarakat karena secara komprehensif belum memberikan perlindungan kepada anak yang berhadapan dengan hukum. ${ }^{24}$

Terkait dengan umur anak, anak yang belum berumur 12 (dua belas) tahun, walaupun melakukan tindak pidana, belum dapat diajukan ke sidang Pengadilan Anak. Hal demikian didasarkan pada pertimbangan sosiologis, psikologis dan paedagogis, bahwa

${ }^{24}$ Gatot Supramono, Op.Cit., h. 117 anak yang belum berumur 12 (dua belas) tahun itu belum dapat mempertanggungjawabkan perbuatannya. Anak yang belum berumur 12 (dua belas) tahun dan melakukan tindak pidana tidak dapat dikenai sanksi pidana maupun sanksi tindakan. Untuk menentukan apakah kepada anak akan dijatuhkan pidana atau tindakan, maka hakim mempertimbangkan berat ringannya tindak pidana yang dilakukan. Di samping itu juga diperhatikan, keadaan anak, keadaan rumah tangga orang tua/wali/ orang tua asuh, hubungan antara anggota keluarga, dan keadaan lingkungannya. Di samping itu hakim juga wajib memperhatikan laporan pembimbing kemasyarakatan. Menurut Undang - Undang Nomor 11 tahun 2012 tentang Sistem Peradilan Pidana Anak, Pasal 69 ayat 2, anak yang belum berusia 14 (empat belas) tahun hanya dapat dikenai tindakan. Sedangkan pasal 70 menyatakan bahwa ringannya perbuatan, keadaan pribadi anak, atau keadaan pada waktu dilakukan perbuatan atau yang terjadi kemudian dijadikan dasar pertimbangan hakim untuk tidak menjatuhkan pidana atau mengenai tindakan dengan mempertimbangkan segi keadilan dan kemanusiaan. Dengan demikian undangundang baru mengubah usia pertanggungjawaban pidana, dari minimal delapan tahun menjadi 12 sampai 18 tahun. Batasan usia yang bisa ditahan 14 sampai 18 tahun.

Didalam Pasal 95 UU Sistem Peradilan Pidana Anak yang memberikan ancaman sanksi administratif dan pasal 96 yang memberikan ancaman pidana penjara paling lama 2 (dua) tahun atau denda paling banyak Rp 200.000.000,00 (dua ratus juta rupiah). Untuk menentukan apakah suatu perbuatan 
Media Komunikasi dan Informasi Hukum dan Masyarakat

dilakukan dengan sengaja yang menimbulkan suatu akibat yang dilarang harus dipelajari ajaran kausalitet.

Menurut Andi Hamzah, berkaitan dengan hal-hal tersebut, dapat diketahui bahwa terjadinya delik hanya pada delik yang mensyaratkan akibat tertentu, yaitu delik materiel, misalnya pembunuhan (pasal 338, pasal $340 \mathrm{KUHP}$ ), penipuan (pasal 378 KUHP) dan delik culpa, misalnya karena kelalaiannya mengakibatkan kematian orang lain (pasal 359 KUHP), karena lalainya, menyebabkan lukanya orang lain (pasal 360 KUHP), dan sebagainya. ${ }^{25}$

Dalam Pasal 338 KUHP bagian inti delik ini adalah "dengan sengaja" serta "merampas nyawa orang lain." Kesengajaan disini ditujukan kepada hilangnya nyawa orang lain, inilah yang membedakan dengan penganiayaan, tidak ada maksud atau kesengajaan untuk menghilangkan nyawa orang. Matinya orang itu hanya akibat dari penganiayaan.

Melihat kasus pembunuhan yang dilakukan oleh anak di bawah umur, berkaitan erat dengan kondisi keluarga dan media massa (koran atau televisi). Meski pada banyak kasus kekerasan impulsif oleh anak biasanya masalah pemicunya sepele, reaksi perilaku yang diberikan anak yang mengalami masalah ini terkadang lebih dari yang dibayangkan. Menendang, memecahkan barangbarang, memukul dan melukai diri sendiri adalah sebagian reaksi perilaku yang dilakukan oleh anak yang melakukan kekerasan impulsif. Anak adalah seorang peniru ulung. Segala gerak geriknya pada awal masa kehidupan didapatnya dari meniru orang di sekitarnya.

${ }^{25}$ Andi Hamzah, 1991, Asas-Asas Hukum Pidana, Jakarta: Rineka Cipta, h. 144
Orangtua dan keluarga adalah tempat belajar pertama kali. Selanjutnya lingkungan akan berkontribusi lebih banyak lagi dalam membuat si anak belajar hal-hal baru termasuk dalam mengungkapkan perasaan dan berperilaku.

Dalam prakteknya selama proses penyidikan dan penanganan anak pelaku tindak pidana pembunuhan, misalnya contoh di wilayah studi Polres Majalengka dalam kasus diatas di tangani oleh unit jatanras/rat, hal ini disebabkan keterbatasan SDM dan Sarana dan prasarana yang belum memadai dan masih menganggap dasar pertimbangan dilakukan menahan anak, adalah karena anak melakukan tindak pidana yang diancam pidana penjara 5 (lima) tahun atau lebih, dikhawatirkan melarikan diri, merusak bukti atau mengulangi tindak pidana. Bila dipahami secara mendalam, dapat diketahui bahwa dasar pertimbangan penahanan anak menurut Pasal 32 ayat (2) Undang-Undang Nomor 11 tahun 2012 adalah Penahanan dilakukan apabila anak melakukan tindak pidana berusia 14 tahun ke atas dan diancam pidana penjara 7 tahun keatas yang ditentukan oleh Undang-Undang.

Jika kepentingan anak menghendaki dilakukan penahanan, maka anak tersebut ditahan. Tetapi apabila kepentingan anak tidak menghendaki, walaupun anak melakukan tindak pidana yang diancam dengan penjara 7 (tujuh) tahun atau lebih, maka tidak dilakukan penahanan. Kepentingan anak disini ialah dipertimbangkannya pengaruh penahanan terhadap perkembangan fisik, mental, dan sosial anak, maka penahanan anak tidak dilakukan. Penahanan dilakukan sebagai upaya terakhir dalam jangka waktu singkat. Mempertimbangkan kepentingan anak, dilibatkan balai pemasyarakatan yang melakukan penelitian terhadap anak nakal, 
Media Komunikasi dan Informasi Hukum dan Masyarakat

dapat juga dilibatkan ahli-ahli seperti kriminolog, psikolog, pemuka agamadan lainlain.

Begitu pula dalam prakteknya selama proses penahanan anak di rumah tanahan Polres Majalengka masih ditempatkan bersama dengan orang dewasa, dimana seharusnya pelaku tindak pidana anak ditempatkan di penahanan anak, harus dipisah dari tempat penahanan orang dewasa dan selama anak ditahan, kebutuhan jasmani, rohani, dan sosial anak harus tetap dipenuhi. Anak ditempatkan lembaga penempatan anak sementara (LPAS) atau lembaga Penyelenggaraan kesejahteraan social (LPKS) apabila belum terdapat LPAS, tempatnya terpisah dari narapidana anak. Hal ini dilatar belakangi pertimbangan psikologis, untuk menghindari akibat negatif sebab anak yang ditahan belum tentu terbukti melakukan kenakalan, bergaul dengan narapidana dikhawatirkan dapat menularkan pengalamannya kepada anak yang berstatus tahanan, dan mempengaruhi perkembangan mentalnya.

Narapidana anak dan tahanan anak, berpengaruh dengan sikap dan tindakan tahanan dewasa. Anak bisa saja mengetahui pengalaman- pengalaman melakukan kejahatan yang belum pernah didengar dan dilakukannya, atau bahkan anak dapat menjadi korban pelecehan seksual selama berada dalam tahanan tersebut dan adanya pemberitaan terhadap anak pelaku tindak pidana ,hal ini mengkwatiran akan merusak metal anak.

Dalam Pasal 2 Undang - Undang Sistem Peradilan Pidana Anak menyatakan bahwa perlindungan anak dimaksudkan untuk melindungi dan mengayomi anak yang berhadapan dengan hukum agar anak dapat menyongsong masa depannya yang masih panjang serta memberi kesempatan kepada anak agar melalui pembinaan akan memperoleh jati dirinya untuk menjadi manusia yang mandiri, bertanggung jawab, dan berguna bagi diri sendiri, keluarga, masyarakat, bangsa, dan negara. Perlindungan anak juga meliputi kegiatan yang bersifat langsung dan tidak langsung dari tindakan yang membahayakan anak secara fisik dan/atau psikis. Dalam hal ini proses peradilan dan penjara bisa membahayakan anak secara fisik dan psikis.

Dalam Undang - Undang Sistem Peradilan Pidana Anak tindak pidana yang diancam pidana di atas tujuh tahun tidak bisa melakukan diversi, dalam hal ini tidak ada bedanya dengan Undang - Undang Nomor 3 Tahun 1997 yang menekankan pada Retributive Justice. Sehingga akan sulit memasyarakatkan anak yang berkonflik dengan hukum agar menjadi orang baik dan berguna, selain itu tertutup peluang untuk menyelesaikan konflik yang ditimbulkan sehingga sulit memulihkan keseimbangan dan mendatangkan rasa damai dalam masyarakat, dan anak yang berkonflik dengan hukum akan sulit berkembang untuk masa depannya karena rasa bersalah yang selalu ada.

Undang-Undang Sistem Peradilan Pidana Anak, acara peradilan pidana anak diatur dalam pasal 16 sampai dengan pasal 62, artinya ada 47 pasal yang mengatur hukum acara pidana anak. Hukum acara pidana disebut juga sebagai hukum pidana formal. Menurut Lamintang, hukum pidana formal memuat peraturan-peraturan yang mengatur tentang bagaimana caranya hukum pidana 
Media Komunikasi dan Informasi Hukum dan Masyarakat

yang bersifat abstrak itu harus diberlakukan secara konkret. ${ }^{26}$

Jaminan perlindungan hak-hak anak juga terdapat dalam pasal 18 yang menyebutkan bahwa dalam menangani perkara anak, anak korban, dan/atau anak saksi, pembimbing kemasyarakatan, pekerja sosial profesional dan tenaga kesejahteraan sosial, penyidik, penuntut umum, hakim, dan advokat atau pemberi bantuan hukum lainnya wajib memperhatikan kepentingan terbaik bagi Anak dan mengusahakan suasana kekeluargaan tetap terpelihara.

Pasal 19 menyebutkan bahwa segala yang berhubungan dengan identitas anak, anak korban, dan/atau anak saksi wajib dirahasiakan dalam pemberitaan di media cetak ataupun elektronik bahkan identitas sebagaimana dimaksud di atas meliputi nama anak, nama anak korban, nama anak saksi, nama orang tua, alamat, wajah, dan hal lain yang dapat mengungkapkan jati diri anak, anak korban, dan/atau anak saksi.

Landasan yuridis lain yang mengatur upaya pembinaan terhadap anak pelaku tindak pidana atau anak yang berkonflik dengan hukum, yaitu Undang-Undang Nomor 11 Tahun 2012 tentang Sistem Peradilan Pidana Anak, yang juga menetapkan bahwa terhadap anak pelaku tindak pidana atau Anak yang Berkonflik dengan Hukum yang telah diputus dikenai sanksi, berupa pidana penjara, terhadapnya akan dilakukan proses pembinaan dalam sistem pemasyarakatan dan ditempatkan secara khusus dalam Lembaga Pemasyarakatan Anak (LPA), tetapi khusus terhadap anak, dalam undang-undang ini

26 P.A.F. Lamintang, 1984, Dasar-Dasar Hukum Pidana Indonesia, Bandung: Sinar Baru, h. 10. tentang sanksi yang dapat dijatuhkan tidak mengikuti ketentuan sanksi tentang pidana pokok yang diatur dalam Pasal $10 \mathrm{KUHP}$, dan menentukan sanksi secara tersendiri yang dituangkan dalam Pasal 71 ayat (1) Undang Undang Nomor 11 Tahun 2012 tentang Sistem Peradilan Pidana Anak, bahwa pidana pokok yang dapat dijatuhkan kepada anak yang berkonflik dengan hukum ialah:

a. pidana peringatan;

b. Pidana dengan syarat (pembinaan luar lembaga, pelayanan masyarakat, pengawasan);

c. pelatihan kerja;

d. pembinaan dalam lembaga;

e. pidana penjara (maksimum 10 tahun).

Dalam hal tindak pidana dilakukan oleh Anak sebelum genap berumur 18 tahun dan diajukan ke sidang pengadilan setelah Anak yang bersangkutan melampaui batas umur 18 tahun, tetapi belum mencapai umur 21 tahun, Anak tetap diajukan ke sidang Anak Menurut Undang - Undang Sistem Peradilan Pidana Anak ketentuan Pasal 84 ayat: (1) anak yang ditahan ditempatkan di LPA; (2) Anak sebagaimana dimaksud pada ayat (1) berhak memperoleh pelayanan, perawatan, pendidikan dan pelatihan, pembimbingan dan pendampingan, serta hak lain sesuai dengan ketentuan peraturan perundang-undangan; (3) LPAS wajib menyelenggarakan pendidikan, pelatihan keterampilan, dan pemenuhan hak lain sesuai dengan ketentuan peraturan perundang-undangan; (4) Pembimbing Kemasyarakatan melakukan penelitian kemasyarakatan untuk menentukan penyelenggaraan program pendidikan sebagaimana dimaksud pada ayat (3); (5) Bapas wajib melakukan pengawasan terhadap 
Media Komunikasi dan Informasi Hukum dan Masyarakat

pelaksanaan program sebagaimana dimaksud pada ayat (4).

Untuk pelaksanaan pembinaan terhadap anak pelaku tindak pidana di Lembaga Pemasyarakatan Anak diatur dalam Pasal 20 Undang-Undang Nomor 12 Tahun 1995 tentang Pemasyarakatan, bahwa dalam rangka pembinaan terhadap anak pidana di Lembaga Pemasyarakatan Anak dilakukan penggolongan berdasarkan: umur, jenis kelamin, lamanya pidana yang dijatuhkan, jenis kejahatan, dan kriteria lainnya sesuai dengan kebutuhan atau perkembangan pembinaan.

Ditahannya anak di Lembaga Pemasyarakatan Anak bukan semata-mata untuk memberikan hukuman kepada anak sebagai pelaku tindak pidana, melainkan anak yang masuk ke lembaga pemasyarakatan anak diberikan pelatihan, pendidikan serta pendekatan terhadap agama dengan mendatangkan para ahli agama anak sesuai dengan agama dan kepercayaannya masingmasing.

Setelah keluarnya anak dari lembaga pemasyarakatan, anak memiliki keahlian tersendiri dan memiliki pengetahuan agama yang tinggi sehingga kedepannya anak diharapkan takut untk mengulangi perbuatannya kembali dan lebih taat lagi dalam beribadah serta diharapkan dapat berguna bagi masyarakat, bangsa dan negara.

$$
\text { Lain halnya jika lembaga }
$$

pemasyarakatan anak hanya memberikan efek jera terhadap anak, maka hal ini dapat berakibat buruk bagi pertumbuhan dan perkembangan mental anak sebagai pelaku tindak pidana, sehingga setelah keluarnya anak dari lembaga pemasyarakatan anak akan takut untuk bersosialisasi karena menganngap dirinya sudah gagal karena sudah pernah ditahan pihak kepolisian. Atau bisa juga jika tidak diberikan pendidikan dan pelatihan anak setelah bebas dari penjara akan semakin jahat sehingga semakin dibenci masyarakat dan dikucilkan dalam kehidupan sehari-hari.

Tujuan dari pembentuk undang-undang dalam menetapkan undang-undang ini pastinya walaupun anak terlibat kasus pidana setelah selesainya anak menjalani hukuman di lembaga pemasyarakatan dapat berguna dan berkarya dalam kehidupannya sehingga masyarakat atau warga sekitarnya lambat laun dapat melupakan kalau si Anak ini pernah terlibat dalam suatu tindak pidana tertentu.

Anak pelaku tindak pidana dihukum setengah hukuman orang dewasa. Anak tidak boleh mendapat hukuman mati, dalam pasal ini yaitu Pasal 45, Pasal 46 dan Pasal 47 KUHP bukan alasan bagi anak pekaku tindak pidana untuk menghapus pidana tetapi hanya untuk meringankan pidana.

Dengan diundangkannya UndangUndang Nomor 11 Tahun 2012 tentang Sistem Peradilan Pidana Anak, maka Undang-Undang Nomor 3 Tahun 1997 dinyatakan tidak berlaku lagi, karena undang-undang tersebut dianggap sudah tidak dapat memenuhi kebutuhan hukum masyarakat, yaitu sebagai pelaku tindak pidana. Dalam Undang- Undang Nomor 11 Tahun 2012 tentang Sistem Peradilan Pidana Anak, anak sebagai pelaku tindak pidana dapat menjamin terlindungnya hak-hak anak, dimulai pada tahap pemeriksaan kepolisian, sampai pemeriksaan di pengadilan sampai dengan pembinaan anak di lapas.

Terhadap anak pelaku tindak pidana pembunuhan berencana diancam Pasal 80 Ayat (3) jo Pasal 76 c Undang-Undang Nomor 35 Tahun 2014 tentang perubahan UndangUndang Nomor 23 Tahun 2002 tentang 
Media Komunikasi dan Informasi Hukum dan Masyarakat

Perlindungan Anak, dengan pidana penjara paling lama 15 tahun dengan denda 3 milyar.

3. Pertimbangan Hukum Hakim Terhadap Anak Sebagai Pekaku Tindak Pidana Pembunuhan Berencana Dalam Putusan Pengadilan Negeri Nomor 16/Pid.SusAnak/2016/PN.Cbn.

Pertimbangan hakim dalam putusan bahwa oleh karena semua unsur dari pasal dalam dakwaan Pertama Primair yang didakwakan kepada Anak Saka Tatal Bin Bagja tersebut telah terpenuhi maka dengan demikian dakwaan Penuntut Umum telah terbukti sehingga Majelis Hakim berpendapat bahwa Anak Saka Tatal Bin Karsila haruslah dinyatakan telah terbukti secara sah dan meyakinkan melakukan tindak pidana "Bersama - Sama Melakukan Pembunuhan Berencana" memenuhi rumusan unsur pasal 340 KUHP jo Pasal 55 ayat (1) ke-1 KUHP sebagaimana dakwaan Penuntut Umum yang didakwakan kepada Terdakwa pada dakwaan Pertama Primair.

Menimbang, bahwa berdasarkan pertimbangan tersebut di atas oleh karena unsur pasal dalam dakwaan Pertama Primair telah terbukti maka dakwaan Pertama Subsidair Atau Kedua Primair, Subsidair, Lebih Subsidiar tidak perlu dipertimbangkan lagi.

Menimbang, bahwa dalam persidangan, Majelis Hakim tidak menemukan hal-hal yang dapat menghapuskan pertanggungjawaban pidana, baik sebagai alasan pembenar dan atau alasan pemaaf maupun juga kelainan kejiwaan yang terdapat pada diri pelaku tindak pidana, maka Anak Saka Tatal Bin Bagja harus mempertanggungjawabkan perbuatannya.

Menimbang, bahwa oleh karena Anak Saka Tatal Bin Bagja mampu bertanggung jawab, maka harus dinyatakan bersalah dan dijatuhi pidana; Menimbang, bahwa dari keterangan Anak Saka Tatal Bin Bagja maupun keterangan ibu kandung Anak Anak Saka Tatal Bin Bagja dan Pembimbing Kemasyarakatan Anak Saka Tatal Bin Karsila pada saat melakukan tindak pidana berusia 15 (lima belas) tahun 6 (enam) bulan, maka kepadanya di perlakukan Undang-Undang No. 11 Tahun 2012 Tentang Sistem Peradilan Pidana Anak.

Menimbang, bahwa menurut UndangUndang Sistem Peradilan Pidana Anak tersebut, terdapat perbedaan penjatuhan pidana dengan KUHP.

Dimana penjatuhan pidana untuk seorang anak ditentukan $1 / 2$ (setengah) dari hukuman maksimum pidana orang dewasa seperti diatur dalam KUHP tujuan dari ketentuan tersebut adalah untuk melindungi dan mengayomi anak agar dapat menyongsong masa depan yang masih panjang.

Menimbang, bahwa dari keterangan lbu Kandung Anak Saka Tatal Bin Bagja dihubungkan dengan hasil Penelitian Pembimbing Kemasyarakatan Cirebon, bahwa Anak Saka Tatal Bin Bagja dalam melakukan tindak pidana tersebut dikarenakan Anak Saka Tatal Bin Bagja kurang pengawasan dari orang tua Anak saka Tatal Bin Bagja, pergaulan yang negatif serta banyaknya waktu luang sehingga digunakan oleh Anak Saka Tatal Bin Bagja untuk melakukan hal yang tidak bermanfaat.

Menimbang, bahwa berdasarkan hal tersebut di atas, maka Majelis Hakim sependapat dengan pendapat Pembimbing Kemasyarakatan, Cirebon dan Sakti Peksos dari Dinas Sosial, Tenaga Kerja dan Transmigrasi Kota Cirebon untuk menjatuhkan 
Media Komunikasi dan Informasi Hukum dan Masyarakat

pidana penjara di LPKA Bandung yang setimpal dengan perbuatan Anak Saka Tatal Bin Bagja karena dengan pidana penjara ini akan membuat Anak Saka Tatal Bin Bagja jera dan dapat mendidik Anak Saka Tatal Bin Bagja sehingga diharapkan Anak Saka Tatal Bin Bagja tidak mengulangi kembali perbuatannya.

Menimbang, bahwa dengan demikian sepanjang mengenai terbuktinya tindak pidana yang dilakukan oleh Anak Saka Tatal Bin Bagja Majelis Hakim Anak Pengadilan Negeri Cirebon sependapat dengan Penuntut Umum, akan tetapi mengenai berat ringannya pidana yang akan dijatuhkan Majelis Hakim Anak Pengadilan Negeri Cirebon akan mempertimbangkan sendiri.

Menimbang, bahwa dalam perkara ini terhadap Anak Saka Tatal Bin Bagja telah dikenakan penangkapan dan penahanan yang sah, maka masa penangkapan dan penahanan tersebut harus dikurangkan seluruhnya dari pidana yang dijatuhkan

Menimbang, bahwa oleh karena Anak Saka Tatal Bin Bagja ditahan dan penahanan terhadap Anak Saka Tatal Bin Bagja dilandasi alasan yang cukup, maka perlu ditetapkan agar Anak Saka Tatal Bin Bagja tetap berada dalam tahanan;

Menimbang, bahwa mengenai barang bukti yang dihadirkan di persidangan bahwa barang bukti tersebut masih diperlukan untuk pemeriksaan perkara atas nama Tersangka Sudirman Bin Suratno Dkk maka terhadap barang bukti tersebut dikembalikan kepada Penuntut Umum untuk dipergunakan dalam perkara atas nama Tersangka Sudirman Bin Suratno Dkk;

Menimbang, bahwa menanggapi pembelaan/Pleidooi yang diajukan oleh Anak Saka Tatal Bin Bagja bahwa apa - apa yang disampaikan oleh Anak Saka Tatal Bin Bagja telah dipertimbangkan oleh Majelis Hakim tersebut di atas dan setelah Majelis Hakim memperhatikan nota Pembelaan/Pleidooi dari Anak Saka Tatal Bin Bagja tersebut ternyata tidak ada bukti yang dapat membuktikan kebenaran Anak Saka Tatal Bin Bagja, oleh karena itu Majelis Hakim berpendapat untuk menolak Pembelaan/ Pleidooi Anak Saka Tatal Bin Bagja;

Menimbang, bahwa suatu pemidanaan adalah dimaksudkan di samping membawa manfaat bagi masyarakat umum, yang terpenting adalah diharapkan agar membawa manfaat dan berguna pula bagi diri pribadi terpidana itu sendiri. Oleh karena itu penjatuhan pidana tidaklah bertujuan sebagai balas dendam dan untuk menimbulkan duka nestapa bagi pelaku tindak pidana, melainkan dimaksudkan agar pelaku tindak pidana kelak dikemudian hari setelah selesai menjalani pidana dapat kembali ke masyarakat menempuh hidup dan kehidupannya secara layak dengan bekal kesadaran penuh yang disertai tekad dan prinsip untuk senantiasa berhati - hati dalam menapaki perjalanan hidup dan kehidupannya serta dapat berusaha menjadi manusia yang berharkat dan bermartabat di tengah - tengah masyarakat ;

Menimbang, bahwa untuk menjatuhkan pidana terhadap Anak Saka Tatal Bin Bagja maka perlu dipertimbangkan terlebih dahulu keadaan yang memberatkan dan yang meringankan Anak Saka Tatal Bin Bagja:

Keadaan yang memberatkan:

- Perbuatan Anak Saka Tatal Bin Bagja dan teman-temannya meresahkan masyarakat;

- Perbuatan Anak Saka Tatal Bin Bagja dan teman-temannya telah membuat Anak 
Media Komunikasi dan Informasi Hukum dan Masyarakat

korban Muhammad Rizky dan Anak korban Vina meninggal dunia;

- Perbuatan Anak Saka Tatal Bin Bagja dan teman-temannya sangat sadis, kejam dan di luar perikemanusiaan;

- Perbuatan Anak Saka Tatal Bin Bagja dan teman-temannya tidak mencerminkan kenalan remaja pada umumnya tetapi sudah menjurus kepada perbuatan yang sangat membahayakan keselamatan masyarakat;

- Keberadaan Anak Saka Tatal Bin Bagja dan teman-temannya kelompok geng motor membuat keresahan, kecemasan dan ketakutan di masyarakat Cirebon;

- Perbuatan Anak Saka Tatal Bin Bagja dan teman-temannya telah membuat keluarga para korban kehilangan orang yang sangat dicintai dan disayangi;

- Anak Saka Tatal Bin Bagja berbelit belt dipersidangkan sehingga menghambat proses pemeriksaan perkara;

Keadaan yang meringankan:

- Anak Saka tatal Bin Bagja masih muda usianya sehingga masih bisa diharapkan untuk memperbaiki tingkah lakunya di masa depan;

- Anak Saka tatal Bin Bagja belum pernah dihukum;

- Anak Saka Tatal Bin Bagja bukanlah pelaku utama, peran Anak Saka Tatal Bin Bagja dalam perkara aquo memukul sekali dan melakukan pelemparan batu ke arah sepeda motor Anak korban Muhammad Rizky;

Menimbang, bahwa oleh karena Anak Saka Tatal Bin Bagja dijatuhi pidana maka haruslah dibebani pula untuk membayar biaya perkara;
Menimbang, bahwa setelah Majelis Hakim Anak Pemeriksa Perkara aquo mempertimbangkan mengenai hal yang memberatkan dan meringankan, maka hukuman yang dijatuhkan kepada Anak Saka Tatal Bin Bagja sudah pantas, layak dan sesuai dengan rasa keadilan hukum dan keadilan masyarakat maupun keadilan bagi korban;

Memperhatikan ketentuan Pasal 340 Jo. Pasal 55 ayat (1) ke-1 KUHPidana, UndangUndang No. 11 Tahun 2012 Tentang Sistem Peradilan Pidana Anak, Undang-Undang Nomor 8 Tahun 1981 Tentang KUHAP dan peraturan lain yang bersangkutan dengan perkara ini :

MENGAD I L I :

1. Menyatakan Anak Saka Tatal Bin Bagja terbukti secara sah dan meyakinkan bersalah melakukan tindak pidana "BERSAMA - SAMA MELAKUKAN PEMBUNUHAN BERENCANA"';

2. Menjatuhkan pidana kepada Anak Saka Tatal Bin Bagja dengan pidana penjara di LPKA Bandung selama 8 (delapan) tahun;

3. Menetapkan masa penangkapan dan penahanan yang telah dijalani oleh Anak Saka Tatal Bin Bagja dikurangkan seluruhnya dari pidana yang dijatuhkan ;

4. Menetapkan Anak Saka Tatal Bin Bagja tetap berada dalam tahanan ;

5. Menetapkan barang bukti berupa:

- 1 (satu) batang bambu bulat ukuran 70 $\mathrm{cm}$;

- 1 (satu) unit Satria FU warna hitam tanpa plat nomor;

- 1 (satu) unit sepeda motor Yamaha Vixion warna merah No.Pol. E-4208-BL;

- 1 (satu) buah handphone merk Samsung warna hitam; 
Media Komunikasi dan Informasi Hukum dan Masyarakat

- 3 (tiga) buah batu ukuran sedang;

- 1 (satu) buah handphone merk Nokia warna abu-abu biru;

- 1 (satu) buah handphone merk Samsung warna hitam;

- 1 (satu) unit sepeda motor merk Honda Beat warna hitam strip orange;

- 2 (dua) buah Aqua kosong (bekas miras ciu);

- 2 (dua) buah kantong plastik bening kosong (bekas miras tuak);

- 1 (satu) botol kosong merek Sprite;

- 1 (satu) botol kosong Big Cola ukuran kecil;

- 1 (satu) buah handphone merk Samsung warna putih;

- 1 (satu) buah handphone merk Nokia warna hitam abu-abu;

- 1 (satu) unit sepeda motor Yamaha Mio warna putih Nopol. E-2848-BJ;

- 1 (satu) buah helm merk KYT warna merah putih;

- 1 (satu) buah switer warna biru dongker;

- 1 (satu) unit sepeda motor Yamaha Xeon warna hijau kuning;

Dikembalikan kepada Penuntut Umum untuk dipergunakan untuk pemeriksaan perkara atas nama Tersangka SUDIRMAN Bin SURATNO Dkk

6. Membebankan biaya perkara kepada Anak Saka Tatal Bin Bagja sebesar Rp 2.500,(dua ribu lima ratus rupiah);

\section{E. Penutup}

\section{Kesimpulan}

Pertanggungjawaban anak sebagai pelaku dalam tindak pidana pembunuhan berencana dalam sistem hukum Indonesia diketahui bahwa Pidana dan jenis pidana penjatuhan Pidana pada Persidangan Anak diatur dalam Pasal 22 sampai dengan 32 Undang-Undang Nomor : 3 Tahun 1997 dan dapat berupa pidana atau tindakan. Apabila diperinci lagi, pidana tersebut bersifat pidana Pokok dan Pidana Tambahan. Pidana Pokok Terdiri dari : Pidana penjara diatur dalam Pasal 26 UU No. 3 tahun 1997 Apabila Anak sebagaimana dimaksud dalam Pasal 1 angka 2 huruf a, Apabila Anak sebagaimana dimaksud dalam Pasal 1 angka 2 huruf a, belum mencapai umur 12 (dua belas) tahun melakukan tindak pidana yang tidak diancam pidana penjara seumur hidup, maka terfadap Anak tersebut dijatuhkan salah satu tindakan sebagaimana dimaksud dalam Pasal 24. Kalau dilihat dari bentuknya maka hukuman penjara dapat berupa seumur hidup untuk sementara. Hukuman penjara untuk sementara mempunyai rentang waktu minimum/algemeene Straftmaxime selama 15 (lima belas) tahun.

Perlindungan hukum terhadap terhadap anak sebagai pelaku tindak pidana pembunuhan berencana dalam Putusan Pengadilan Negeri Nomor 16/Pid.SusAnak/2016/PN.Cbn Perlindungan Hukum Pada Anak Pelaku Tindak Pidana Berdasarkan Undang - Undang Nomor 11 Tahun 2012, dari hasil kajian dinyatakan bahwa Anak yang berhadapan dengan hukum, meliputi anak sebagai korban atau anak sebagai pelaku tindak pidana, sudah selayaknya anak yang berhadapan dengan hukum mendapat perlindungan hukum baik pelaku maupun korban. Prosedur penanganannyapun berbeda dengan orang dewasa. Bagi anak sebagai pelaku tindak pidana, proses penyidikan, penuntutan, dan pemeriksaan di pengadilan hukum acaranya berbeda dengan pengadilan orang dewasa. Begitupun dalam proses 
Media Komunikasi dan Informasi Hukum dan Masyarakat

penyelidikan dan penyidikan tindak pidana korban dan pelaku anak berdasarkan Surat Kapolri Nomor : ST/39/99 tanggal 29 Maret 1999 tentang Ruang Pelayanan Khusus dan peraturan Kapolri Nomor 10 tahun 2007 tentang susunan Organisasi tata kerja dilingkungan Kepolisian, bagi anak berhadapan dengan hukum masuk dalam Unit Khusus Perlindungan Perempuan dan anak (yang disebut Unit PPA) yang berada dibawah langsung Satuan Reskrim.

Pertimbangan hukum hakim terhadap anak sebagai pelaku tindak pidana pembunuhan berencana dalam Putusan Pengadilan Negeri Nomor 16/Pid.SusAnak/2016/PN.Cbn, Perbuatan Anak Saka Tatal Bin Bagja dan teman-temannya meresahkan masyarakat; Perbuatan Anak Saka Tatal Bin Bagja dan teman-temannya telah membuat Anak korban Muhammad Rizky dan Anak korban Vina meninggal dunia; Perbuatan Anak Saka Tatal Bin Bagja dan teman-temannya sangat sadis, kejam dan di luar perikemanusiaan; Perbuatan Anak Saka Tatal Bin Bagja dan teman-temannya tidak mencerminkan kenalan remaja pada umumnya tetapi sudah menjurus kepada perbuatan yang sangat membahayakan keselamatan masyarakat; Keberadaan Anak Saka Tatal Bin Bagja dan teman-temannya kelompok geng motor membuat keresahan, kecemasan dan ketakutan di masyarakat Cirebon; Perbuatan Anak Saka Tatal Bin Bagja dan temantemannya telah membuat keluarga para korban kehilangan orang yang sangat dicintai dan disayangi; Anak Saka Tatal Bin Bagja berbelit belt dipersidangkan sehingga menghambat proses pemeriksaan perkara; Menyatakan Anak Saka Tatal Bin Bagja terbukti secara sah dan meyakinkan bersalah melakukan tindak pidana "BERSAMA - SAMA MELAKUKAN PEMBUNUHAN BERENCANA"'; Menjatuhkan pidana kepada Anak Saka Tatal Bin Bagja dengan pidana penjara di LPKA Bandung selama 8 (delapan) tahun, yang mana putusan ini menurut majelis hakim sudah sangat tepat dengan segala pertimbangan yang memberatkan dan meringankan karena hukuman bagi anak sebagai pelaku tindak pidana adalah $1 / 2$ dari hukuman pokok, dimana hukuman pokok terhadap pembunuhan berencana ini sesuai ketentuan Pasal 340 KUHP adalah 20 Tahun jadi setengah dari hukuman ini adalah maksimal 10 Tahun, jadi penerapan hukuman 8 Tahun adalah sudah termasuk wajar.

\section{Saran}

Diharapkan pertanggung jawaban hukum terhadap anak pelaku tindak pidana pembunuhan berencana dapat memberikan efek jera agar tidak ada perbuatan serupa dimasa yang akan datang tapi juga tidak pula menghancurkan masa depan anak.

Diharapkan perlindungan hukum terhadap anak walau sebagai pelaku tetap diberikan agar anak tidak merasa tertekan dan sendiri dalam menghadapi hukum.

Diharapkan hakim dalam menjatuhkan pidana terhadap pelaku anak tindak pidana pembunuhan berencana memberikan pelajaran yang berarti bagi kehidupan terpidana. 
Media Komunikasi dan Informasi Hukum dan Masyarakat

\section{Daftar Bacaan}

Agus Rusianto, 2016, Tindak Pidana dan Pertanggung Jawaban Pidana, Jakarta, Prenada media Group,

Bambang Sunggono, 2003, Metode Penelitian Hukum, Jakarta, PT. Raja Grafindo Perkasa

Bismar Siregar dkk. 1986, Hukum dan HakHak Anak. Jakarta : Rajawali.

E.Y.Kanter \& S.R Sianturi. 2002, Asas-asas Hukum Pidana di Indonesia dan Penerapannya. Jakarta: Storia Grafika.

Kitab Undang - Undang Hukum Pidana

LH Permana. 2016. Analisis Pertimbangan Hukum Hakim Dalam Penjatuhan Pidana Di Bawah Minimum Terhadap Pelaku Tindak Pidana Kesusilaan. Lampung. Jurnal. Fakultas Hukum. Universitas Lampung.

Maidin Gultom. 2008, Perlindungan Hukum Terhadap Anak, Bandung, PT Refika Aditama

Marlina, 2009, Peradilan Pidana Anak Di Indonesia. "Pengembangan Konsep Diversi dan Restorative Justice", Bandung, PT. Refika Aditama,

Moeljalento, 2008, Asas-Asas Hukum Pidana, Edisi revisi, Jakarta, Renika Cipta

Ninik Widiyanti dan Panji Anoraga, 1987. Perkembangan Kejahatan dan Masalahnya, Jakarta: Pradya Paramita

Undang-Undang Republik Indonesia Nomor 35 Tahun 2014 Tentang Perubahan Atas Undang-Undang Nomor 23 Tahun 2002 Tentang Perlindungan Anak

Undang-Undang Republik Indonesia Nomor 11 Tahun 2012 Tentang Sistem Peradilan Pidana Anak

United Nation Standard Minimum Rules for the Administration of Juvenile Justice (the Beijing Rules) Adopted by General Assembly resolution 40/33 tanggal 29 November 1985. 